\title{
PROBLEM AS OPPORTUNITY: METACOGNITIVE LEARNING FOR DOCTORAL STUDENTS DURING THE PANDEMIC
}

\author{
Raqib Chowdhury* \\ Faculty of Education, Monash University \\ Received 26 November 2020 \\ Revised 20 December 2020; Accepted 15 January 2021
}

\begin{abstract}
Our pre-pandemic hubris of touting our times as an advanced digital age has given way to misgivings and scepticism as we slowly realise the limits of technological advances and how our teaching and learning practices have not been able to completely sever from age-old traditions. With unprecedented changes triggered by the global pandemic which saw schools close and move on to online spaces within the span of a few weeks all the world over, there has been a flurry of academic research into student disengagement, better integration of technology and best practices in adaptation of teaching and learning. However, much less attention has been paid to the needs of educators themselves as learners, such as those engaged in the essentially solitary experience of doctoral studies, often characterised by writer's block, procrastination or lack of motivation.

Yet the COVID-19 scenario has opened up splendid and unprecedented opportunities for reflection into our own practices. This paper critically considers the value of metacognition and self-regulated learning which current circumstances can nurture in unique ways. Studies have shown that the use of metacognitive strategies which help learners understand their own learning - can amount to several months of progress. Much more than just learning to learn, such strategies also activate prior knowledge and make learners become higher-order agents overlooking their own learning while also being part of it, thereby leading to independent and transferrable practice. Drawing on anecdotal case studies of the presenter's doctoral students, the paper will offer insights into ways in which early-career researchers can become effective and self-regulated learners who can take control of their own cognitive and motivational processes in planning, monitoring and evaluating skills and practices. In particular, the paper will propose guidelines through which a "securitization" can be achieved for a "post-pandemic pedagogy" (Murphy, 2020) for doctoral studies.

Key words: metacognitive learning, self-regulated learning, autoethnography, COVID-19, self-evaluation, doctoral studies, $\mathrm{PhD}$, graduate research
\end{abstract}

\section{Introduction}

As any doctoral student would be well aware, $\mathrm{PhD}$ studies are much more than a few years' journey at the end of which the student submits a thesis as evidence of the creation of new knowledge. It is also a long-term training which involves the learning of new, more generic and transferrable skills - from time management and self-discipline to personal development and intercultural competence, and perhaps most importantly, the acquisition and development of a distinct academic identity and agency. A doctorate, after all, is not just a scholar or an intellectual expert on a particular topic or disciplinary knowledge, but someone who has, at least ideally, committed to bringing positive changes to society. Their personal growth as independent scholars is therefore of

\footnotetext{
Tel.: (+61 3) 99055396

Email: raqib.chowdhury@monash.edu
}

paramount importance, as much as the creation of new knowledge.

Yet it is common for doctoral students to prioritise the end product - their theses - over their own learning and development as intellectual beings who grow and continue to grow. It is in this sense that Golde and Dore (2001, as cited in Cahusac de Caux, 2019, p. 10) point out that doctoral students often do not "clearly understand what doctoral study entails". The thought that their research is "most important' often forces them to neglect their personal growth and wellbeing (Pretorius, 2019) and makes them espouse an approach whereby the end product (the thesis) becomes the sole measure of success, at the cost of neglecting the messy process that eventuates it.

The current impact of the whirlwind of the global COVID-19 pandemic and the lockdowns that have characterised the daily lives of millions of researchers worldwide has only 
highlighted this problem in unprecedented ways. In these times, the position of graduate and early career researchers has become particularly precarious (Murphy, 2020). In fact, a recent study in the UK (Byrom, 2020) found that more than three-quarters of graduate researchers experienced a negative impact on their data collection, discussion, writing, and dissemination of ideas due to the lockdown. More than half of the participants in this study expressed concerns about data analysis, while a third of the respondents complained about having insufficient access to software or technology required for research. Perhaps most tellingly, half of the respondents reported being very stressed, while two thirds were concerned about their future plans. So serious is this situation, that in Australia, where I work, universities' response to the pandemic has been said to represent "one of the most significant and rapid shifts in the delivery of schooling for the whole country since the Second World War" (Deeble, 2020).

All this indicates the tremendous bite of the vastly different environments in which we find ourselves in, working towards our already stressful research commitments, and the need for adaptation. In the face of the compounding challenges involving the pressure to publish or perish, work-life balance, isolation, career insecurity and interpersonal conflicts, students often resort to over- or under-commitment to other tasks, procrastination, perfectionism, and affected by what has come to be known as the 'imposter syndrome'.

As the virus began to spread across the world and people around the world slowly began realising the unprecedented effects that this would have on their work, scholarly research on its effects correspondingly saw a sharp rise, especially on use of technology and best practices in running online classrooms. While a lot of these were based on personal experiences and anecdotal evidence (for example, Aydemir \& Ulusu, 2020), a number of empirical studies have also been done (for example, Byrom, 2020; Murphy, 2020). What is clearly lacking is research on educators themselves, and the challenges they were facing in their own learning. While this would typically refer to ongoing professional development, in the case of $\mathrm{PhD}$ students, this is also learning about their own learning, or, rather learning on their own, where the focus is not so much on technology or coping with it, but self-mediated and self-regulated strategies that can enhance their learning.

In plain, jargon-free terms, this paper is about the importance of self-awareness, of looking inside rather than outside, and understanding the mostly fallacious attribution to technology our failures and the slowness in the pace of our work as researchers in the current situation. How can we minimise our risk of disengagement as learners to ensure a securitisation of higher education in the times to come? I propose that one of the ways in which this can be done is by accepting, understanding and putting into practice the belief that the processes of producing work, such as writing a $\mathrm{PhD}$ thesis, is as important as the end product, the thesis. Raising our metacognitive awareness by engaging in self-dialogue and reflection can help us better understand these processes.

The current paper is based on my reflections as a doctoral supervisor with ten supervised completions to date and current supervision of eight doctoral students at a major Australian university. Anecdotal observations from the past six months tell me that the present and ongoing lockdown situation has affected and is affecting doctoral students in vastly different ways, and not all of these in negative ways. While some students have complained of feeling enormous pressure in continuing their research under the lockdown, away from reallife interactions with their supervisors and doctoral mates, others have said that the new situation has made them more aware of how they can optimise their habits for more fruitful outcomes in the times to come. This convinces me that it is possible to create meaningful and original research while working independently without regular and direct contact with supervisors, and without the need of much technology.

In the light of these experiences I offer insights into ways in which early-career researchers, especially doctoral students, can become effective and self-regulated learners who are able to take control of their own cognitive and motivational processes in planning, monitoring and evaluating their knowledge, skills and practices. After all, theory aside, metacognition is essentially a personal practice where learners intuitively 
learn from their past experiences. In this paper I would also like to highlight the real-life and pragmatic aspects of metacognition and the benefits of integrating these into the day to day academic activities of doctoral students, especially at times when supervisory and social contact with fellow researchers are minimal.

I will first present a brief overview of metacognition and its associated concept of self-regulated learning. I will then reflect on my observations as a doctoral supervisor and suggest two specific and practical ways through which metacognition and self-regulated learning can be achieved. The paper concludes by looking into the future where a postpandemic reality awaits us with newer demands that we can prepare for within the current realities of our research work.

\section{Knowing thyself - Metacognition}

Although scholars have tried to pin it down within specific disciplines, the rapidly growing field of metacognition has traditionally involved interdisciplinary research. In identifying contemporary strands in research on metacognition, Azevedo (2020), chief editor of the Metacognition and Learning journal for nearly a decade, draws on interdisciplinary research from educational psychology, cognitive and developmental psychology, learning and computational sciences and STEM education. $\mathrm{He}$ laments the current lack of "attempt at integrating them into a unified theory" (p. 92) and calls for more theoretical research to be done towards attaining a unified definition of metacognition. Perhaps such lack explains why educational researchers often shy away from research into metacognition, assuming that it lies beyond the stretch of their cognate areas.

Most commonly attributed to American developmental psychologist John Flavell, metacognition refers to his work on children's learning in the 1970s which looked into how they controlled their own memory processes. Although the works of Vygotsky did not address metacognition per se, his theories can be considered as a precursor (Bråten, 1991). In particular, his theories of cognitive development address the role of self-regulation in learning, and the relationship between self-awareness and self-regulation. Most previous research has one finding in common - that a strategic and premeditated, or 'designed-in' (Hammond \&
Gibbons, 2005), rather than incidental (or casual) use of cognitive processes - such as memory and attention, and activation of prior knowledge - are fundamental parts of learning. It is only through conscious awareness - that is, metacognition - and ongoing monitoring, that a learner can utilise their prior knowledge and cognition most productively.

Metacognition involves the processes of planning, monitoring and evaluation and then making changes based on these in one's own learning behaviours. Planning involves thinking about learning goals and considering which strategies or tools to use to achieve them; while monitoring involves the active implementation of the plan as well as tracking own progress. In the final phase - that of evaluation - learners consider the success (or failure) of their strategy in terms of achieving their goals. Throughout these three phases, the recursive elements of reflection and self questioning are essential. Given the recursive nature of $\mathrm{PhD}$ thesis writing, this becomes especially significant for doctoral researchers.

Often used interchangeably, metacognition usually involves two dimensions (Tarricone, 2011). The first is metacognitive knowledge (declarative), or what learners know about their own learning, their cognitive abilities, their perception of the task, and the resources, tools and strategies available to them to execute the tasks. The second dimension is metacognitive regulation or skills (procedural) - what learners do about learning, based on the first metacognitive knowledge. This includes how they monitor and control cognition, such as choosing the appropriate strategy when others do not work. While metacognitive knowledge helps learners make necessary adjustments to learning contexts, metacognitive skills (or strategies) involve the practicalities of planning, monitoring, and evaluating (Flavell et al. 2002) that help the learner regulate their strategies. In essence, understanding of metacognition has implications on how we situate learning itself through reasoning, problem solving, and conceptual understanding for learners from all disciplines and age groups, regardless of their topic or stage of learning.

This is especially true for doctoral students because of the independent nature of their work, and the length of time needed to write the doctoral thesis, often punctuated with other commitments, including family and personal 
responsibilities, full or part-time work and, perhaps most commonly, teaching. Azevedo (2020) explains that the nature of metacognition is dependent on such contexts and the nature of the task (in this case, doctoral writing), and involves reflection of personal experiences, judgments and evaluations of one's own knowledge and skills. Together they shape how one arrives at decision-making. Our idiosyncratic ways of learning and personalities play a part in this too; so too contextual variables, such as institutional expectations of the $\mathrm{PhD}$ student, personality traits and the home environment. The latter no doubt is of crucial importance in the current circumstances of the global pandemic.

Finally, it is important to understand the differences, but more so, the relationship between cognition and metacognition. Winne (2018) shows that these two are part of a shared and interdependent process, effectively meaning that such strategies, while activating one's prior knowledge and making them a higher-order agent overlooking their own learning, also positions them as being part of it, thereby leading to independent practice. Together cognition and metacognition constitute what we refer to as self-regulated learning, which I discuss next.

\section{Self-regulated Learning}

As the two elements of self-regulation, cognition and metacognition are synthesised when learners understand, then complete a task, and finally are able to transfer their learning to similar tasks in the future through the cycle of planning, monitoring and evaluation (Evidence for Learning, 2020). Whereas cognitive skills are task-specific (Schuster, Stebner, Leutner \& Wirth, 2020), metacognitive skills are transferable to a wide variety of learning tasks, including thesis writing.

This of course does not mean that the transfer happens automatically. Self-regulated learning is a deliberate process in which three components - cognition, motivation and metacognition - merge and govern learning (Schraw et al. 2006, as cited in Schuster et al., 2020). In this, "learners set goals for their learning and then attempt to monitor, regulate and control their cognition, motivation and behaviour, guided and constrained by their goals and the contextual features of the environment" (Pintrich 2000, as cited in Schuster et al., 2020). Triggering metacognitive activities therefore require conscious effort and decisive action. In fact, studies have shown that consciously paying attention to one's metacognitive processes can enhance its benefits. In the tradition of classical behaviourist theories of learning, then, this means that through repeated practice, it is possible for one to 'condition' themselves into making metacognitive learning with less effort and to greater benefit.

Effective self-regulated learners are characterised by being good at setting goals (these could be daily or even hourly), being able to distinguish between effective and ineffective strategies in attaining these goals, carefully monitoring self progress, being adaptable to physical environments (currently this would mean working from home), and being good at time-management and prioritisation of tasks. It is important to understand that these phases constitute a cycle rather than a checklist to be ticked off in any order. Although still not automatic, as learners become increasingly confident in their application of metacognitive strategies, the process becomes spontaneous and effortless, as I will note below in relation to the experiences of my doctoral students.

\section{Reflections: Supervisor Learning from Students}

In 'normal' times, doctoral students in my faculty have access to a large open space working area on the top floor of the faculty building. This spacious, well-lit, 24-hour access hub is self-sufficient with various amenities such as computer dock and monitor equipped individual workstations, a fully equipped kitchen, resting and group discussion areas, as well as photocopiers, lockers and stationery rooms. The open nature of the workstations gives students a community feeling as they interact and have conversations with their colleagues all day long.

The COVID-19 lockdown meant that these doctoral students lost access to this area and for the last seven months were mostly confined to their rooms, with only occasional online meetings with their supervisors and almost no contact with their fellow PhD colleagues. The second, Stage 4 lockdown in Melbourne was 
stricter, with restrictions on travelling beyond a $5 \mathrm{~km}$ radius from home and limited hours of outdoor activities. One would think that by this stage students would have lost their patience and verging on breaking down, both mentally and physically. Although this might have been true in some cases, it was surprising what anecdotal evidence suggests. Through $\mathrm{PhD}$ supervisory meetings, I came to realise a strange, unprecedented development - that my doctoral students were faring better this time, complaining less, and generally being more productive. They told me that lessons learnt from the first lockdown had made them less susceptible to the restrictions of working from home.

In itself this might be hardly surprising, as we all learn to adapt to new circumstances in the face of pressure or lack of choices. However, what was unique about their adaptation was that they reported that they were more in harmony with themselves and that they knew better what worked for them as they continued engaging in the writing of their thesis. With no other choice, these students reported that the isolating experiences opened up opportunities for them to look 'inside' rather than 'outside' and to better learn about their own learning. Such metacognitive awareness, then, was facilitated by the forced isolation that they found themselves in and enhanced their learning at a time when no other options were available. I noticed too, that in my own work, perhaps for the first time in such a sustained manner, I became more introspective about my learning behaviours. Generally, I felt more aware of how I could optimise the time and physical spaces that were available to me during the lockdown. I realised with greater clarity the spatiotemporal conditions that were most conducive to my studies and research. In many ways similar to my students, I felt that the more I consciously attempted to and learnt about my own learning, the more effective I could become as a learner.

Now that we have looked at the benefits of metacognition and how these can lead to selfregulated learning, especially for doctoral students, and within the current realities of the pandemic, I will discuss two practical ways of triggering, activating and exercising metacognitive awareness leading to a more optimised selfregulated learning. I acknowledge that these would not equally be practicable for all doctoral students, however an awareness of our own idiosyncratic learning habits has benefits that can be carried on as a life-long orientation to how one can be most productive in the face of adversity and strife. Two of the activities my doctoral students engaged in during this time included Shut up and Write (SUNW) groups and autoethnographic writing. Needless to say, these were spontaneous choices that the students made, rather than conscious and deliberate choices that were a priori informed by the aforementioned theories of metacognition.

\section{Critical Friendships through SUNW}

Group writing sessions, such as the 'Shut Up and Write!' (SUNW) movement have gained increased popularity among graduate researchers and doctoral researchers (O'Dwyer et al., 2017) in recent years, and in particular this year as the pandemic has restricted our physical movement around the world. These self-regulated sessions, where writing 'rounds' are punctuated by short break sessions, have provided enormous opportunities for peer feedback and scaffolding, critical friendship, and metacognitive learning. As Mewburn, Osbourne and Caldwell (2014, p. 400) note, SUNW sessions can create "informal learning opportunities to support doctoral writing" in ways that rarely happen through and within formal and structured learning environments, such as in classrooms, workshops, or even oneon-one supervisory meetings.

Developed first in the early 2000 s to promote good practices for non-academic writing (such as for journalists and media writers), SUNW was meant to offer a community of practice (Wenger, 1998) through writing sessions in public places, such as cafes. Typically, a session would involve a solid onehour writing 'cycle', followed by a short coffee break and then another writing cycle. Through the cycles the writers can move in and out without disrupting others, while in the inbetween discussion sessions, they would briefly provide a summary of what they have done and are planning to do next. Importantly, unless someone asks for specific feedback, these discussions do not solicit or provide feedback, but are based on non-judgemental and respectful discussions and negotiation of meaning (Viete \& Ha, 2007; Viete \& Peeler 2007; Ryan \& Viete, 2009), achieved through peer scaffolding. The learning occurring in 
these spaces can be understood through Vygotskian theories of the mediated nature of learning through dialogue and interaction. Mewburn et al. (2014) argue that compared to the more formal and structured sessions (such as workshops or even supervisory meetings), SUNW sessions can promote informal, flexible and productive self-regulated writing practices. Such learning, they argue, can also be more empowering because of the way it allows a greater sense of ownership of learning.

A recent study by Chakma, $\mathrm{Li}$ and Kabuhung (2020, upcoming) shows how a group of three graduate research students formed highly efficient collaborative practices of writing during the COVID-19 lockdown in Melbourne through an ongoing daily SUNW group over a period of five months. These collaborative online sessions facilitated them into sharing their work and soliciting critical feedback on a daily basis. Over a period of time, as they learnt more about their own learning styles, they were able to optimise the writing cycles to better suit them to their individual needs. Through "passive accountability" (n.p.), they ensured that they were keeping up to their plans, something they reported was harder to do when they worked on their own, in pre-pandemic times.

Over a period of five months, the three participants of this session progressed from formulating their research questions to writing their literature reviews and designing their methodologies. For those at a more advanced stage, the sessions saw them writing their analysis and discussion chapters. Notably, while all students where from the same faculty, they each worked on a different topic, and because of the lockdown, these writing sessions were held entirely online using the Internetbased video conferencing tool Zoom, the university's digital repositories and workspaces such as Google Drive and Google Doc.

Purposive (rather than random or conversational) and rich metacognitive talk in such online environments facilitates unique opportunities to learn from the self and others and practice reasoning, discussion, arguing and explanation. In fact, virtual spaces work better because they push the learner towards the outer bounds of the zone of proximal development (Wass, Harland, \& Mercer, 2011) through peer scaffolding using techniques such as the think- aloud protocol (Berne, 2004), whereby learners vocalise their thinking in real time during conversations so that their speech becomes an audible extension of their minds and thinking. In summary, used in a sustained manner over a period of time, SUNW can offer the graduate researcher opportunities to ask challenging questions to peers, build critical friends and enhance metacognitive awareness of their own learning, all the while within the privacy of their own homes.

\section{The Power of Autoethnographies}

As doctoral students write their theses, they are also on a journey to understand themselves; they are "people in the process of figuring out what to do, how to live, and the meaning of their struggles" (Bochner \& Ellis, 2006, as cited in Pretorius \& Cutri, 2019, p. 30). Within the realm of social sciences research, personal reflections can well be part of a thesis by allowing a nuanced discovery and understanding of the more complex layers of how we 'make sense' of social realities (our topic of investigation) around us (I discussed the role of criticality in the social sciences in IGRS 2018). Autoethnographic accounts, in which the researcher voice is privileged, can be integrated into the thesis whereby the doctoral student provides narratives of their cognitive growth and enables a more sophisticated understanding and development of their own identity as scholars (Nelson, 2018). For doctoral students, as Pretorius and Cutri (2019, p. 30) put it - "the doctoral experience cannot be fully explored or written about from an outsider's objective experience. It is complex and multifaceted, incorporating various influences, opinions, thoughts, feelings, and experiences".

Writing is as much a cognitive process as it is a social one. Yet institutional expectations often involve an overemphasis on the end product - the thesis, with a corresponding devaluation of the writing process. The recursive and 'messy' nature of academic writing is ignored. When we read a journal article or a book chapter, we only ever see the end product, which is often written by accomplished writers and is in their final accepted form. This leads to frustration for doctoral students when they compare their halfbaked, incomplete and haphazard writing with 
these finely written and polished articles. However, the neatness of this writing belies the messiness of the process which made the final product possible. By drawing upon personal experiences of growth and challenges, autoethnographies allow a frank and honest acknowledgement of the messiness that is almost always attendant to social sciences research, especially as we are choosing and integrating theories and making methodological choices.

Autoethnographic research therefore "humanizes research by focusing on life as 'lived through' in its complexities" (Adams, Ellis, \& Jones, 2017, p. 8), and gives a better understanding of the realities in which they are immersed (Pretorius \& Cutri, 2019, p. 33). Researcher reflexivity, expressed through autoethnographic writing, "acknowledges and accommodates subjectivity, emotionality, and the researcher's influence on research" (Ellis et al., as cited in Pretorius \& Cutri, 2019) and this includes metacognitive learning.

While autoethnography has been taken up prominently in mainstream research in the West in recent years, in many countries social sciences research is still characterised by an emphasis on a more objectivist, 'scientific' and disinterested stance based on a positivist paradigm. This leaves little room for reflective writing, including autoethnographies. The current situation offers us opportunities to think about and integrate the personal struggles that are attendant to our theoretical and methodological choices as we navigate through them while working towards the final version of our theses. The inclusion and acknowledgement of these personal stories in the thesis can provide powerful epistemological insights into the mind of the researcher and better situate their growth as intellectual beings. As Pretorius and Cutri (2019, p. 30) put it, "the doctoral environment can be seen as a different cultural world - something made clear as the reader enters the world of the authors' autoethnographies".

\section{COVID-19: Problem as Opportunity}

Our pre-pandemic hubris of touting our times as an 'advanced' digital age has given way to misgivings and scepticism as we slowly realise the limits of technological advances and how our teaching and learning practices have not been able to completely sever from age-old traditions. It is now well known that incidental or non-judicious use of technology cannot promote learning; to be effective and to improve our learning, technology has to be informed by effective pedagogy, as explained by Koehler and Mishra's (2009) now wellknown TPACK model.

In addition, the exponential speed at which modern technologies are evolving and the corresponding rapid obsolescence of 'old' technology are impacting not just how we teach our students and adapt to the situation, but how we ourselves cope as teachers. When teachers themselves are also learners, such as in the case of doctoral students, this becomes more complicated. It is hoped that through groups such as SUNWs and methodological choices such as autoethnographies, doctoral students would be able to turn the current crisis into a unique opportunity of self-discovery and reflective contemplation, attuned to positive learning outcomes as budding researchers. The slower than usual pace at which we are currently working is the perfect condition for reflective and introspective practices such as metacognitive and self-regulated learning.

\section{Conclusion}

We write in private. We learn in public lectures. Get books from public libraries. We discuss our ideas in public tutorials and seminar groups. But reading and writing happen in private. In silence. And therefore often in shame (Firth, 2013).

Currently, as I write this paper, Murphy (2020) argues that in our hope for an "emancipatory post-pandemic pedagogy", there is need for a "desecuritization of face-to-face schooling" and an "open discourse" which cannot be fully realised when securitisation is in process, such as now. Broadly, the theory of securitisation concerns the processes through which the state enables and rationalises decisions in the name of security and national economic stability. Such decisions in turn enable social commitments that are premised on collective public acceptance of what is good for the state. In this case, we refer to decisions states around the world have taken or are taking in the name of keeping the education sector afloat in the face of an uncertain future. It is important for us educators to have a voice in 
planning contingencies for the desecuritisation of learning when the pandemic is over.

Preventative measures and nonpharmaceutical interventions such as "social" or "physical distancing" in otherwise dense communities such as university campuses to minimise community contact have dramatically reduced interpersonal contact and the widespread closure of schools. The physicality of the classroom experience is now a distant memory in many parts of the world. The costs of moving to online spaces for such extended periods of time are still not fully known. Our goal needs to be to ensure the securitisation of the back to classroom face-to-face instruction. Murphy (2020, p. 492) is concerned that the full extent of the challenges associated with the "securitization of higher education for postpandemic pedagogy" will not be realised for some time, given the unprecedented nature of the current global pandemic.

In such unprecedented times, in the absence of physical seminars and workshops, supervisory contact, the importance of looking beyond our immediate research tasks - such as writing a doctoral thesis - has never been more important. Studying during isolation gives us opportunities to pause and think, and not only create self-initiated communities of practice, such as SUNW, but also learn and practise new methodologies, such as the autoethnography. Combining these two facilitates the conditions that make it possible to understand the practicalities and limitations of our chosen study design, data analysis and even genre knowledge of the various ways of communicating and disseminating our research including presenting at conferences and effectively writing for journals.

As an educational intervention, just like differentiated instruction (my IGRS 2019 presentation), metacognition is not expensive to implement; nor does it require special training or specialist equipment, or indeed broad institutional infrastructure. Metacognitive awareness is more of a cultural shift of the mind and introspective outlook that allows an openness of working in newer, more productive ways that can ensure greater professional growth in a post-COVID19 environment. Metacognitive practices create a teacher of oneself, in oneself - an inner voice that guides the self through a spontaneous internal process of perpetual evaluation of performance. A metacognitive approach to learning allows learners to understand and then take control of their own learning and acquire transferrable skills - transferrable not only to new learning contexts but to new tasks and to the yet unknown specifics of the post-COVID reality that awaits us, hopefully in the near future.

An academic or scholarly life and a lifelong commitment to pursuing intellectual curiosity can be a highly enriching and fulfilling experience. However, it is important for us to know and accept that this involves both joys and sorrows in the production of work. Through metacognitive practices and self-regulated learning, we can securitise the future of our education through fine-tuning our own beliefs, behaviours and practices as educators of the future.

Perhaps, then, it is time for us to move away from an overreliance on technology during these isolating times. Perhaps it is wiser to explore deeply into ways in which we learn best. Perhaps the best use we can make of these times is by resorting to what had worked best to us before technology took over; by looking into and questioning our own practices and ways of learning.

Perhaps, the best way to learn is by unlearning what we have learnt and by learning how to learn anew.

\section{References}

Adams, T. E., Ellis, C., \& Jones, S. H. (2017). Autoethnography. In J. Matthes, C. S. Davis \& R. F. Potter (Eds.), The international encyclopedia of communication research methods. Wiley.

Aydemir, D., \& Ulusu, N. N. (2020). Challenges for PhD students during COVID-19 pandemic: Turning crisis into an opportunity. Biochemistry and Molecular Biology Education, 48(5), 428-429. https://doi.org/10.1002/bmb.21351

Azevedo, R. (2020). Reflections on the field of metacognition: Issues, challenges, and opportunities. Metacognition and Learning, (15), 91-98. https://doi.org/10.1007/s11409-020-09231-x

Berne, J. (2004). Think-aloud protocol and adult learners. Adult Basic Education, 14(3), 153.

Bråten, I. (1991). Vygotsky as precursor to metacognitive theory: II. Vygotsky as metacognitivist. Scandinavian Journal of Educational Research, (35)4, 305-320. https://doi.org/10.1080/0031383910350406

Byrom, N. (2020). COVID-19 and the research community: The challenges of lockdown for early- 
career researchers. eLife 2020 9:e59634. https://doi.org/10.7554/eLife.59634

Cahusac de Caux, B. (2019). A short history of doctoral studies. In L. Pretorius, L. Macaulay \& B. Cahusac de Caux (Eds.), Wellbeing in doctoral education (pp. 9-17). Springer.

Chakma, U., Li, B., \& Kabuhung, G. (upcoming). Creating online metacognitive spaces: Graduate research writing during the covid-19 pandemic.

Deeble, M. (2020, July 16). Evidence for Learning's rapid response to Covid-19. Social Ventures Australia. https://www.socialventures.com.au/sva-quarterly/evidencefor-learnings-rapid-response-to-covid-19/

Evidence for Learning (2020). Metacognition and self-regulated learning. https://www.evidenceforlearning.org.au/guidancereports/metacognition-and-selfregulated-learning/

Firth, K. (2013). Generative writing \& \#shutupandwrite. Research Degree Insiders. https://researchvoodoo.wordpress.com/2013/05/07/gen erative_writing/

Hammond, J., \& Gibbons, P. (2005). Putting scaffolding to work: The contribution of scaffolding in articulating ESL education. Prospect, (20)1, 6-30.

Koehler, M., \& Mishra, P. (2009). What is technological pedagogical content knowledge (TPACK)? Contemporary issues in technology and teacher education, 9(1), 60-70.

Mewburn, I., Osborne, L., \& Caldwell, G. (2014). Shut up $\&$ write! Some surprising uses of cafés and crowds in doctoral writing. In C. Aitchison \& C. Guerin (Eds.), Writing groups for doctoral education and beyond (pp. 218-232). Routledge.

Murphy, M. P. A. (2020). COVID-19 and emergency eLearning: Consequences of the securitization of higher education for post-pandemic pedagogy. Contemporary Security Policy, 41(3), 492-505.

Nelson, R. (2018). Creativity crisis: Toward a postconstructivist educational future. Monash University Publishing.

O'Dwyer, S. T., McDonough, S. L., Jefferson, R., Goff, J. A., \& Redman-MacLaren, M. (2017). Writing groups in the digital age: A case study analysis of Shut Up \&
Write Tuesdays. In A. Esposito (Ed.), Research 2.0 and the impact of digital technologies on scholarly inquiry (pp. 249-269). IGI Global.

Pretorius, L. (2019). Prelude: The topic chooses the researcher. In L. Pretorius, L. Macaulay \& B. Cahusac de Caux (Eds.), Wellbeing in doctoral education (pp. 3-8). Springer.

Pretorius, L., \& Cutri, J. (2019). Autoethnography: Researching personal experiences. In L. Pretorius, L. Macaulay \& B. Cahusac de Caux (Eds.), Wellbeing in doctoral education (pp. 27-34). Springer.

Ryan, J., \& Viete, R. (2009). Respectful interactions: Learning with international students in the Englishspeaking academy. Teaching in Higher education, 14(3), 303-314.

Schuster, C., Stebner, F., Leutner, D., \& Wirth, J. (2020). Transfer of metacognitive skills in self-regulated learning: An experimental training study. Metacognition Learning, 15, 455-477. https://doi.org/10.1007/s11409-020-09237-5

Tarricone, P. (2011). A taxonomy of metacognition. Academic Press.

Viete, R., \& Ha, P. L. (2007). The growth of voice: Expanding possibilities for representing self in research writing. English Teaching: Practice and Critique, 6(2), 39-57.

Viete, R., \& Peeler, E. (2007). Respectful encounters: Valuing each other in teacher professional learning contexts. In A. Berry, A. Clemans \& A. Kostogriz (Eds.), Dimensions of Professional Learning (pp. 177190). Brill Sense.

Wass, R., Harland, T., \& Mercer, A. (2011). Scaffolding critical thinking in the zone of proximal development. Higher Education Research \& Development, (30)3, 317-328. https://doi.org/10.1080/07294360.2010.489237

Wenger, E. (1998). Communities of practice: Learning, meaning, and identity. Cambridge University Press.

Winne, P. H. (2018). Cognition and metacognition within self-regulated learning. In D. Schunk \& J. A. Greene (Eds.), Handbook of self-regulation of learning and performance (pp. 254-270). Routledge. 


\title{
BIẾN NGUY THÀNH CƠ: NGHIÊN CÚUU SINH HỌC TẬP THẾ NÀO THỜI COVID?
}

\author{
Raqib Chowdhury
}

\author{
Khoa Giáo dục, Đại học Monash
}

Tóm tắt: Trước khi bùng phát đại dịch Covid-19, thời đại kỹ thuật số tiên tiến mà ta luôn tự hào ngợi ca nay phải nhường chỗ cho những băn khoăn nghi ngờ khi ta dần vỡ lẽ về̀ những giới hạn của tiến bộ công nghệ và nhận ra cách dạy-học của chúng ta không phải lúc nào cũng thoát được khỏi những truyền thống lâu đời. Trước những biến đổi không tiền khoáng hậu mà đại dịch toàn cầu này gây ra, một đại dịch khiến trường học khắp nơi phải đóng cửa, chuyển sang dạy-học trực tuyến, hàng loạt nghiên cứu đã được tiến hành để hiểu rõ tình trạng phân ly của người học, để tích hợp công nghệ và cách dạy-học tốt hơn vào công việc hàng ngày của ngành giáo dục nhằm thích nghi với tình trạng 'bình thường mới'. Tuy nhiên, các nghiên cứu còn rất ít quan tâm tới chính nhu cầu của nhà giáo dục và cũng đồng thời là người đi học, chẳng hạn như những nghiên cứu sinh đang trong thời gian 'cấm túc trong trại sáng tác' luận án, thời gian mà họ phải cách ly, hoãn hủy bao công việc hoặc thiếu hứng khởi.

Tuy nhiên, đại dịch Covid-19 đã mở ra nhiều cơ hội cũng không tiền khoáng hậu để ta chiêm nghiệm lại chính công việc của mình. Bài viết này xem xét giá trị, lợi ích có thể nói là độc đáo của siêu nhận thức và tự điều chỉnh đối với việc học tập mà hoàn cảnh hiện nay có thể đem lại. Nhiều nghiên cứu chỉ ra rằng việc sử dụng các chiến lược siêu nhận thức giúp người học hiểu thêm về chính việc học của mình, và có thể đẩy nhanh tiến độ học tập thêm nhiều tháng. Không chỉ học cách học, những chiến lược đó còn kích hoạt kiến thức đã có và nâng tầm tư duy của người học để họ có thể quan sát quá trình học tập đồng thời với việc học tập của mình; nhờ đó, họ có thể có được những cách học độc lập và đa dụng trong nhiều hoàn cảnh. Dựa trên những trường hợp cụ thể của nghiên cứu sinh do tác giả bài viết này hướng dẫn, bài viết đưa ra cái nhìn sâu về quá trình những nghiên cứu sinh - những người mới bước vào con đường học thuật - có thể tự điều chỉnh học tập một cách hiệu quả như thế nào, có thể kiểm soát quá trình nhận thức và động cơ của mình như thế nào để hoạch định, theo dõi và đánh giá những kỹ năng, thói quen mà họ rèn giũa được. Đặc biệt, bài viết cũng đề xuất định hướng nhằm 'phổ cập' phương pháp sư phạm ‘hậu đại dịch' (Murphy, 2000) đối với nghiên cứu sinh.

Tù khóa: siêu nhận thức, tự điều chỉnh học tập, Covid-19, tự đánh giá, nghiên cứu sinh, nghiên cứu tự ngã 